\title{
Self-evaluation of body image in sport active and sport inactive adolescent girls
}

\author{
Janka Peráčková ${ }^{1, *}$, Alžbeta Chovancová ${ }^{2}$, Klaudia Kukurová1, and Lucia Plevková1 \\ ${ }^{1}$ Faculty of Physical Education and Sports, Comenius University in Bratislava, Bratislava, Slovakia; and ${ }^{2}$ Primary School \\ Budatinska, Bratislava, Slovakia
}

Copyright: (C) 2018 J. Peráčková et al. This is an open access article licensed under the Creative Commons Attribution License (http://creativecommons.org/licenses/by/4.0/).

\begin{abstract}
Background: Body image is the mental representation one creates about one's self and is in relation how others see him/her. In the scientific literature, there is a lack of knowledge concerning differences in self-evaluation of body image in sport active and sport inactive adolescent girls. Objective: The aim of this study was to investigate satisfaction or dissatisfaction in an individual attitudinal disposition toward the physical self-body image perception with regards to the level of physical activity (sport active and sport inactive) of adolescent girls in two dispositional dimensions: evaluation and orientation for three somatic domains of appearance, fitness and health/illness. This study aimed to investigate how body image was affected with regard to female adolescents' extracurricular level of physical activity. Methods: In the study 105 sport active adolescent girls (age $16.21 \pm 1.54$ years) and 49 sport inactive adolescent girls (age $16.99 \pm .76$ years) participated. We used the Multidimensional Body-Self Relations Questionnaire (MBSRQ). For comparison of satisfaction with the perceptions of their own body image in sport active and sport inactive girls MANOVA and Mann-Whitney $U$ test were used. Results: Our results show that the factor group (sport active or sport inactive adolescent girls) does not significantly affect "body image" represented with the answers to the items of MBSRQ $\left(\lambda=.898, F(10,143)=1.63, p=.103, \eta^{2}=.102\right)$. Conclusion: This study shows that the level of physical activity does not significantly influence body image in the selected sample of sport active and sport inactive female adolescents.
\end{abstract}

Keywords: female pupils, physical activity, body satisfaction

\section{Introduction}

Nowadays, the power of the image in a life of an individual is significant (McCabe \& Ricciardelli, 2003; Siegling \& Delaney, 2013; Wertheim \& Paxton, 2012). Body-image, or how we see our physical selves, and how we believe other people see us, is the mental representation one creates, and is an important part of who we are (Savva, 2014). Our perceived imperfections, especially in adolescence do not only affect how we feel but also what we do. It strongly influences individuals' behaviour (Franko \& Striegel-Moore, 2002; McCabe \& Ricciardelli, 2009; Moore, 1988; Pujols, Meston, \& Seal, 2010). Appearance-oriented society has negative impact, mostly on adolescent girls, how they perceive the reality of their own body (Clay, Vignoles, \& Dittmar,

\footnotetext{
* Address for correspondence: Janka Peráčková, Department of Sports Educology and Sports Humanistic, Faculty of Physical Education and Sports, Comenius University in Bratislava, Nábr. arm. gen. L. Svobodu 9, 81469 Bratislava, Slovakia. E-mail: janka.perackova@uniba.sk
}

2005; Davison, 2012). Concern over the image of one's own body is rapidly growing throughout the developed world. Rating of satisfaction resp. dissatisfaction of one's own body has never been as high in the past as it is in the present millennium (Bucchianeri, Arikian, Hannan, Eisenberg, \& Neumark-Sztainer, 2013). Although it may have been perceived and evaluated, it did not mention a body that is ultra slim. The preferred figure of the woman is "Venus", which highlighted femininity and the beauty of the fullness of the body (Bovet \& Raymond, 2015). As population pressure is growing by presenting "body ideals", we have a greater need to ponder and solve it to a certain extent. Many factors influence this rate. Many researchers showed great dissatisfaction with body image in their results (Knauss, Paxton, \& Alsaker, 2007; Möller \& Bothma, 2001; Paxton, Eisenberg, \& Neumark-Sztainer, 2006; Stice \& Whitenton, 2002). An importance that is attached to one's body image or appearance of a man, regardless of whether he or she realizes it or not, is evaluated many times also according to how he or she perceives his or her body 
and what reactions he or she evokes to his/her appearance in society (Girard, Rodgers, \& Chabrol, 2018). Adolescence is a period of an individual's development when a young person prepares to live, to function independently from family, and prepare for reproduction role (Smetana, 2011). The period is a preparation for love, marriage, and parenthood (Silliman \& Schumm, 2004). This is the period of observing the surroundings, listening to, learning to own and other's experiences. This is the period of perception of one's own body from his/her own perspective and the perspective of members of society. The age range of adolescence falls within World Health Organization's definition of young people, which refers to individuals between ages 10 and 24 (World Health Organization, 2018).

Cash (2004) characterized body image as a multidimensional attitude to its body and appearance. This attitude is also a concept of physical appearance, combining all the elements of a human mental perception of himself/herself, such as perception, thinking, feelings, attitudes, physical appearance and the influence of this physical appearance on human behaviour (DiGioacchino, Sargent, \& Topping, 2001). Body image is a construct encompassing how we perceive, think, feel, and act toward our body (Cash, 2004).

Body image formation is a process that is influenced by gender, age, media, and the cognitive process of expectations, values, and attitudes within a culture (Fisher, 1990; Volkwein \& McConatha, 1997).

Fialová (2006) adds by its ideas that it is the creation of a personal image of the body and the attitudes towards it, where these attitudes contain information about the body from external and internal sources, information from the environment and individual perception of its own body, his/her subjective body experience.

The development of perception of an individual's body is complex. We perceive body image that is difficult to understand. Body image is part of self-perception and self-evaluation and is an emotional component of self-perception. Furnham, Badmin, and Sneade (2002) determined that an adolescent girl's self-esteem is linked to a lean body image. Exercising for health reasons is positively associated with self-esteem for women and for men too (McDonald \& Thompson, 1992).

Several authors (Medeková, 2008; Pačesová, 2016) dealt with the issue of self-perception in Slovakia, however they did not use the Multidimensional Body-Self Relations Questionnaire (MBSRQ), which has often been applied in studies in many countries.

The aim of our work was to broaden the knowledge about body image and at the same time to inform about the different assessment of satisfaction with the body in sport active and sport-inactive adolescent girls. This study was particularly devoted to investigating satisfaction or dissatisfaction in an individual attitudinal disposition toward the body image perception of sport active and sport inactive adolescent girls in ten subscales of MBSRQ. This study aimed to investigate how body image was affected with regards to female adolescents' extracurricular level of physical activity.

\section{Methods}

\section{Participants}

We recruited girls from secondary school in Bratislava. Girls aged 15-18 years were asked to participate in the research. Only the girls whose parents provided written informed consent to their participation were included in the study. The procedures of the research were in accordance with the ethical standards of the ethics committee and with the Helsinki Declaration of 1975, as revised in 2000. The sample consisted of 154 female adolescents divided into two groups - sport active and sport inactive based on the level of participation in extracurricular sporting activities (Table 1). Based on the literature we examined (Grgic et al., 2018; Huang \& Yamamoto, 2013; Martinéz-Pardo, Romero-Arenas, Martínez-Ruiz, Rubio-Arias, \& Alcaraz, 2014; Murlasits, Reed, \& Wells, 2012), we can talk about the development of physical abilities already at the frequency of two extracurricular training units per week. Sport active participants were those who exercised at least twice a week (at least 120 minutes) of extracurricular physical activity weekly and sport inactive were those who exercised less than two extracurricular hours in a week. They all attended two compulsory Physical Education lessons in school weekly. The number of sport active adolescent girls was 105 and the number of sport inactive adolescent girls was 49 . The age of sport active adolescent girls was $16.21 \pm 1.54$ years. The age of sport inactive adolescent girls was $16.99 \pm 0.76$ years. There was no statistical significance in selected features in comparison between sport active and sport inactive adolescent girls.

Table 1

Mean $\pm S D$ of basic anthropometric parameters in sport active and inactive girls

\begin{tabular}{lrc}
\hline & $\begin{array}{c}\text { Sport active } \\
(n=105)\end{array}$ & $\begin{array}{c}\text { Sport inactive } \\
(n=49)\end{array}$ \\
\hline Body height $(\mathrm{cm})$ & $167.03 \pm 6.11$ & $166.38 \pm 6.55$ \\
Body weight $(\mathrm{kg})$ & $56.86 \pm 7.44$ & $57.23 \pm 7.50$ \\
Body mass index $\left(\mathrm{kg} / \mathrm{m}^{2}\right)$ & $20.89 \pm 2.67$ & $21.28 \pm 2.91$ \\
Body fat $(\%)$ & $26.43 \pm 4.12$ & $27.55 \pm 5.24$ \\
\hline
\end{tabular}




\section{Procedures}

The girls completed a standardized questionnaire the Multidimensional Body-Self Relationship Questionnaire (referred to as MBSRQ; Cash, 1994) focusing on self-evaluation of body image. Using a standard "forward-backward" translation procedure, the English language version of the questionnaire was translated into a Slovak version by two independent translators who translated from the source to the target language and then after two weeks they translated the questionnaire from Slovak language into English. Then they met and made correction of the Slovak version by the consensus of both emphasizing conceptual rather than literal translations, as well as the need to use natural and acceptable language for the broadest target group of research sample. They both were familiar with terminology of the area of research. For each question the girls had a choice of five options from 1 to 5 , where 1 means definitely disagree and 5 means definitely agree. A 69-item self-report inventory for assessment of selfattitudinal aspects of the body image is divided into 10 subscales; each subscale belongs to specific questionnaire statements. The perception of overall body image is assessed within ten variables of the MBSRQ, which are: Appearance Evaluation, Appearance Orientation, Fitness Evaluation, Fitness Orientation, Health Evaluation, Health Orientation, Illness Orientation, Overweight Preoccupation, Body Areas Satisfaction, Self-Classified Weight. MBSRQ subscale scores are the means of the constituent items after revising contra-indicative items. The higher score of the subscale means the higher satisfaction of the respondent from her body image (Cash, 2000). Higher satisfaction means that if the values at each subscale exceeded the rating level of 3 .

\section{Statistical analysis and interpretation}

To assess whether the sport active girls showed greater satisfaction with the assessment of individual subscales perceptions of their own image body as sport inactive girls we used MANOVA's multidimensional statistical method (MANOVA - multivariate analysis of variance). For comparing two independent groups (sport active adolescent girls and sport inactive adolescent girls) we used Mann-Whitney $U$ test in each dependent variable of the subscales of the MBSRQ separately. We used the statistical program IBM SPSS Statistics (Version 17 for Windows; SPSS, Chicago, IL, USA). Significance was considered at $p<.05$.

\section{Results}

In our case, we want to examine the dependence of the ten variables which characterize "body image" on a factor group (sport active girls, sport inactive girls). MANOVA's results showed that the factor group (sport active or sport inactive adolescent girls) does not significantly affect the "body image" $(\lambda=.898, F(10$, $\left.143)=1.63, p=.103, \eta^{2}=.102\right)$. Table 2 presents descriptive statistics of all subscales for a group of sport active adolescent girls and sport inactive adolescent girls.

Both sport active and sport inactive adolescent girls reached the lowest average value in the subscale of Overweight Preoccupation (2.41 and 2.46). In all other subscales, the mean values in both groups were at the top of the scale (greater than 3). Unambiguously, the highest average value was in both groups in the Health orientation subscale (sport active girls 3.52 and sport inactive girls 3.73).

Table 2

Mean $\pm S D$ and statistical significance of differences between sport active and inactive girls in individual subscales of the MBSRQ

\begin{tabular}{lccc}
\hline & $\begin{array}{c}\text { Sport active } \\
(n=105)\end{array}$ & $\begin{array}{c}\text { Sport inactive } \\
(n=49)\end{array}$ & $p$ \\
\hline Appearance Evaluation & $3.31 \pm 0.81$ & $3.25 \pm 0.70$ & .906 \\
Appearance Orientation & $3.27 \pm 0.36$ & $3.38 \pm 0.42$ & .206 \\
Fitness Evaluation & $3.19 \pm 0.60$ & $3.48 \pm 0.85$ & .041 \\
Fitness Orientation & $3.05 \pm 0.43$ & $3.13 \pm 0.43$ & .178 \\
Health Evaluation & $3.02 \pm 0.43$ & $3.05 \pm 0.55$ & .900 \\
Health Orientation & $3.52 \pm 0.64$ & $3.73 \pm 0.69$ & .140 \\
Illness Orientation & $3.01 \pm 0.74$ & $3.04 \pm 0.76$ & .786 \\
Body Areas Satisfaction Scale & $3.20 \pm 0.68$ & $3.08 \pm 0.73$ & .626 \\
Overweight Preoccupation & $2.41 \pm 0.93$ & $2.45 \pm 0.86$ & .650 \\
Self-Classified Weight & $3.10 \pm 0.60$ & $3.18 \pm 0.80$ & .523 \\
\hline
\end{tabular}


Sport inactive adolescent girls showed higher average values in eight subscales (Appearance Orientation, Fitness Evaluation, Fitness Orientation, Health Evaluation, Health Orientation, Illness Orientation, Overweight Preoccupation, Self-Classified Weight) and only in two scales (Appearance Evaluation, Body Areas Satisfaction) higher average values were found in sport active adolescent girls (Table 2). One subscale, Fitness Evaluation recorded $p=.041$ statistical significance in comparison between sport active and sport inactive adolescent girls.

We investigated if differences exist in mean scores between sport active and sport inactive girls in perceiving the own body and if they are statistically significant in the effect of one or more independent variables on several dependant variables at the same time.

With the help of multivariate analysis in the mean scores of each of the variables (MBSRQ subscales), we found that there are no statistically significant differences in perceiving the own body between the sport inactive adolescent girls and sport active adolescent girls.

\section{Discussion}

Our findings are comparable to some authors, who reported lower or the same satisfaction with body image in comparison to sport active and sport inactive individuals (Hausenblas \& Mack, 1999; Lim, OmarFauzee, \& Rosli, 2011; Pačesová, 2016).

On the contrary, there is some other research in which sport active adolescent girls are more satisfied with their bodies than sport inactive adolescent girls. The study of authors Peráčková and Peráček (2016) among 352 adolescent girls (197 sport active and 155 sport inactive) concluded that the sport active girls were more satisfied with the body image represent with 10 subscales of MBSRQ than their sport inactive counterparts were. The results of their study revealed that sport active adolescent girls reached higher means in seven of the scales (Fitness Evaluation, Fitness Orientation, Health Evaluation, Health Orientation, Illness Orientation, Appearance Evaluation, Body Areas Satisfaction) and only in three scales reached higher means sport inactive adolescent girls (Appearance Orientation, Overweight Preoccupation, Self-Classified Weight).

Pačesová and Šmela (2016) in the sample of 257 adolescent girls reveal more positive perception $(p<.05)$ of own body in a group of sport active adolescent girls than in sport inactive adolescent girls.

Several authors (Finkenberg, DiNucci, McCune, \& McCune, 1993; Tiggemann \& Williamson, 2000) found that women regard exercise as a way to solve the problem with their body image and they are then ultimately, more satisfied with their own body.

Our results show that there was not a statistical difference between sport active and sport inactive adolescent girls, that the effects of group membership on the 10 body image subscales are not statistically significant.

What is also important is that sport active adolescent girls become motivated to perform physical activity when they should not be based on feeling good, but should be done for feelings of well-being, because at that time physical activity improves their physical satisfaction and self-confidence (McDonald \& Thompson, 1992; Silberstein, Striegel-Moore, Timko, \& Rodin, 1988; Tiggemann \& Williamson, 2000). Women's motivation to exercise is related to weight and tone because of their dissatisfaction with them (McDonald \& Thompson, 1992).

Sports are considered as a factor increasing individuals' level of body perception. It is also thought that athletes care about health, appearance, fitness and physical competence and are more satisfied with body parts because of their muscled body structure developing due to the exercises. Hauesenblas and Downs (2001) found that athletes had a more positive body image compared to the nonathletes.

From the scientific literature it does not seem that nonathletes have more positive body image. The researchers of only 3 studies from a review of the 78 research studies (ibid) have found that athletes report lower or similar body image concerns compared to nonathletes (Anderson, Zager, Hetzler, NahikianNelms, \& Syler, 1996; Fulkerson, Keel, Leon, \& Dorr, 1999; Hausenblas \& Mack, 1999).

It would be beneficial if similar research were further expanded and enriched with results in Slovakia as well as in another part of the world, because it is still a very important issue. This topic is current and more problematic in adolescent ages. One of the options that should be explored is why the adolescent sport active girls are a little bit worse in observed subscale items. It would also be interesting to find out why the subjects do exercise. We believe that this paradox, which has disproved our theoretical groundwork is caused by the fact that the sport active adolescent girls from our group are less satisfied with their own body and therefore try to pay attention to physical activity and its benefits, such as weight loss, body forming and body tone and therefore they attended extracurricular physical activities. 


\section{Conclusion}

The research results do not point to differences between sport active and sport inactive adolescent girls in perceiving the own body. We found no significant differences between sport active adolescent girls and sport inactive adolescent girls in attitude to own body.

The results of our work showed, that sport inactive adolescent girls are slightly more satisfied with the perception of the items of 8 individual subscales of the body image questionnaire than sport active adolescent girls. Sport active adolescent girls had higher average values in 2 subscales: Appearance Evaluation and Body Areas Satisfaction.

\section{Conflict of interest}

There were no conflicts of interest.

\section{Acknowledgments}

This study was supported by the Comenius University in Bratislava [grant no. VEGA 1/0726/17].

\section{References}

Anderson, S. L., Zager, K., Hetzler, R. K., Nahikian-Nelms, M., \& Syler, G. (1996). Comparison of Eating Disorder Inventory-2 (EDI-2) scores of male bodybuilders to the male college student subgroup. International Journal of Sport Nutrition, 6, 255-262.

Bovet, J., \& Raymond, M. (2015). Preferred women's waistto-hip ratio variation over the last 2,500 years. PLoS ONE, 10(4), e0123284.

Bucchianeri, M. M., Arikian, A. J., Hannan, P. J., Eisenberg, M. E., \& Neumark-Sztainer, D. (2013). Body dissatisfaction from adolescence to young adulthood: Findings from a 10-year longitudinal study. Body Image, 10, 1-7.

Cash, T. F. (1994). Users' manual for the Multidimensional Body-Self Relations Questionnaire. Norfolk, VA: Old Dominion University.

Cash, T. F. (2000). Body image. In A. E. Kazdin (Ed.), The encyclopedia of psychology (pp. 436-439). Washington, DC: American Psychological Association.

Cash, T. F. (2004). Body image: Past, present, and future. Body Image, 1, 1-5.

Clay, D., Vignoles, V. L., \& Dittmar, H. (2005). Body image and self-esteem among adolescent girls: Testing the influence of sociocultural factors. Journal of Research on Adolescence, 15, 451-477.

Davison, T. E. (2012). Body image in social contexts. In T. F. Cash (Ed.), Encyclopedia of body image and human appearance (pp. 243-249). Amsterdam, Netherlands: Academic Press.
DiGioacchino, R. F., Sargent, R. G., \& Topping, M. (2001). Body dissatisfaction among White and African American male and female college students. Eating Behaviours, 2, 39-50.

Fialová, L. (2006). Moderní body image. Jak se vyrovnat s kultem štíhlého těla [Modern body image. How to deal with the cult of a thin body]. Prague, Czech Republic: Grada.

Finkenberg, M. E., DiNucci, J. M., McCune, S. L., \& McCune, E. D. (1993). Body esteem and enrolment in classes with different levels of physical activity. Perceptual and Motor Skills, 76, 783-792.

Fisher, S. (1990). The evolution of psychological concepts about the body. In T. F. Cash \& T. Pruzinsky (Eds.), Body images (pp. 3-20). New York, NY: Guilford Press.

Franko, D. L., \& Striegel-Moore, R. H. (2002). The role of body dissatisfaction as a risk factor for depression in adolescent girls: Are the differences Black and White? Journal of Psychosomatic Research, 53, 975-983.

Fulkerson, J. A., Keel, P. K., Leon, G. R., \& Dorr, T. (1999). Eating-disordered behaviors and personality characteristics of high school athletes and nonathletes. International Journal of Eating Disorders, 26, 73-79.

Furnham, A., Badmin, N., \& Sneade, I. (2002). Body image dissatisfaction: Gender differences in eating attitudes, selfesteem, and reason for exercise. Journal of Psychology, 136, 581-596.

Girard, M., Rodgers, R. F., \& Chabrol, H. (2018). Prospective predictors of body dissatisfaction, drive for thinness, and muscularity concerns among young women in France: A sociocultural model. Body Image, 26, 103-110.

Grgic, J., Schoenfeld, B. J., Davies, T. B., Lazinica, B., Krieger, J. W., \& Pedisic, Z. (2018). Effect of resistance training frequency on gains in muscular strength: A systematic review and meta analysis. Sports Medicine, 48, 1207-1220.

Hausenblas, H. A., \& Downs, D. S. (2001). Comparison of body image between athletes and nonathletes: A metaanalytic review. Journal of Applied Sport Psychology, 13, 323-339.

Hausenblas, H. A., \& Mack, D. E. (1999). Social physique anxiety and eating disorder correlates among female athletic and nonathletic populations. Journal of Sport Behavior, 22, 502-513.

Huang, H. N., \& Yamamoto, T. (2013). The effects of balance training frequency on the balance ability in healthy young adults. Journal of Exercise Physiology, 16, 86-94.

Knauss, C., Paxton, S. J., \& Alsaker, F. D. (2007). Relationships among body dissatisfaction, internationalisation of the media body ideal and perceived pressure from media in adolescent girls and boys. Body Image, 4, 353-360.

Lim, C. L. S., Omar-Fauzee, M. S., \& Rosli, M. H. (2011). The body dissatisfaction among female athletes and nonathletes in Malaysia. Journal of Asia Pacific Studies, 2, 55-69.

Martinéz-Pardo, E., Romero-Arenas, S., Martínez-Ruiz, E., Rubio-Arias, J. A., \& Alcaraz, P. E. (2014). Effect of a whole-body vibration training modifying the training frequency of workouts per week in active adults. Journal of Strength and Conditioning Research, 28, 3255-3263.

McCabe, M. P., \& Ricciardelli, L. A. (2003). Sociocultural influences on body image and body changes among 
adolescent boys and girls. Journal of Social Psychology, 143, 5-26.

McCabe, M. P., \& Ricciardelli, L. A. (2009). Extreme weight change behaviours: Are overweight and normal weight adolescents different, and does this vary over time? European Eating Disorders Review, 17, 301-314.

McDonald, K., \& Thompson, J. K. (1992). Eating disturbance, body image dissatisfaction, and reasons for exercising: Gender differences and correlational findings. International Journal of Eating Disorders, 11, 289-292.

Medeková, H. (2008). Telesné sebaponímanie u dievčat stredoškoláčok [Physical self-perception in girls from high school]. Slovenská antropológia, 11(2), 43-48.

Möller, A. T., \& Bothma, M. E. (2001). Body dissatisfaction and irrational beliefs. Psychological Reports, 88, 423-430.

Moore, D. C. (1988). Body image and eating behavior in adolescent girls. American Journal of Diseases of Children, 142, 1114-1118.

Murlasits, Z., Reed, P. J., \& Wells. K. (2012). Effect of resistance training frequency on physiological adaptations in older adults. Journal of Exercise Science and Fitness, 10, 28-32.

Pačesová, P. (2016). Spokojnost’ s telom adolescentiek z hladiska vykonávania športovej aktivity [Body satisfaction of adolescent girls in terms of sport activity]. In J. Peráčková et al. (Eds.), Telesné sebaponímanie školskej športujúcej a nešportujúcej populácie (pp. 156-162). Bratislava, Slovakia: Comenius University in Bratislava.

Pačesová, P., \& Šmela, P. (2016). Telesné sebaponímanie adolescentov v súvislosti s vybranými aspektami športovania [Physical self-perception of adolescents in relation to selected aspects of sport]. In M. Merica, M. Imrovič, M. Lukáč, \& M. Daško (Eds.), Vedecké práce KSS a $P$ 2016: vedecký zborník (pp. 279-285). Trnava, Slovakia: University of Ss. Cyril and Methodius in Trnava.

Paxton, S. J., Eisenberg, M. E., \& Neumark-Sztainer, D. (2006). Prospective predictors of body dissatisfaction in adolescent girls and boys: A five-year longitudinal study. Developmental Psychology, 42, 888-899.

Peráčková, J., \& Peráček, P. (2016). Body image športujúcich a nešportujúcich adolescentov [Body image of adolescent athletes and nonathletes]. In J. Peráčková et al. (Eds.),
Telesné sebaponímanie školskej športujúcej a nešportujúcej populácie (pp. 6-136). Bratislava, Slovakia: Comenius University in Bratislava.

Pujols, Y., Meston, C. M., \& Seal B. N. (2010). The association between sexual satisfaction and body image in women. Journal of Sexual Medicine, 7, 905-916.

Savva, M. (2014). Body image: How we see ourselves and others; how this can lead to problems. North Charleston, SC: CreateSpace Independent Publishing Platform.

Siegling, A. B., \& Delaney M. E. (2013). Toward understanding body image importance: Individual differences in a Canadian sample of undergraduate students. Eating Disorders, 21, 117-129.

Silberstein, L. R., Striegel-Moore, R. H., Timko, C., \& Rodin, J. (1988). Behavioral and psychological implications of body dissatisfaction: Do men and women differ? Sex Roles, 19, $219-232$.

Silliman, B., \& Schumm, W. R. (2004). Adolescents' perceptions of marriage and premarital couples education. Family Relations, 53, 513-520.

Smetana, J. G. (2011). Adolescents, families, and social development: How teens construct their worlds. Chichester, United Kingdom: Wiley-Blackwell.

Stice, E., \& Whitenton, K. (2002). Risk factors for body dissatisfaction in adolescent girls: A longitudinal investigation. Developmental Psychology, 38, 669-678.

Tiggemann, M., \& Williamson, S. (2000). The effect of exercise on body satisfaction and self-esteem as a function of gender and age. Sex Roles, 43, 119-127.

Volkwein, K., \& McConatha, J. T. (1997). Cultural contours of the body - the impact of age and fitness. In R. Lindor \& M. Bar-Eli (Eds.), Innovations in sport psychology: Linking theory and practice (pp. 744-746). Tel Aviv, Israel: International Social Survey Programme.

Wertheim, E. H., \& Paxton, S. J. (2012). Body image development - adolescent girls. In T. F. Cash (Ed.), Encyclopedia of body image and human appearance (pp. 187-193). Amsterdam: Academic Press.

World Health Organization. (2018). Adolescent health and development. Retrieved from http://www.searo.who.int/ entity/child_adolescent/topics/adolescent_health/en/ 